\title{
Baseline CD4 lymphocyte count among HIV patients in Kano, Northern Nigeria
}

\author{
Emmanuel E. Nwokedi,* Ochicha Ochicha, Aminu Z. Mohammed and Nasiru M. Saddiq \\ Departments of Medical Microbiology \& Pathology*, Bayero University / Aminu Kano Teaching Hospital, Kano, \\ Nigeria; P.M.B. 3452 Kano, Nigeria
}

*Address for Correspondence: Dr E.E. Nwokedi; Department of Microbiology / Parasitology Aminu Kano Teaching Hospital; P.M.B. 3452 Kano, Nigeria

\section{SUMMARY}

HIV causes immunodeficiency by infection, lyses and depletion of CD4 T-lymphocytes; hence CD4 count has become a valuable indicator of immune function in the management of HIV infection. Consequently, we evaluated baseline CD4 counts of 500 HIV seropsitive adults in a government sponsored anti-retroviral treatment (ART) scheme at our centre, for the purpose of monitoring subsequent response to anti-retrovirals. The overwhelming majority $(92 \%)$ of our patients were within the sexually active, 3 rd to 5 th decade age group, and the mean CD4 count was 302 cells $/ \mu$ l. Half of our patients (251 cases) had AIDS as defined by CD4 count $<200$ cells $/ \mu \mathrm{l}$ and $72 \%$ had CD4 count $<350$ cells $/ \mu$, the WHO recommended criterion for instituting ART. In general our HIV seropositives had CD4 counts comparable to other studies here in Nigeria and the West African sub-region, but higher than in East Africa and Europe. In view of the well documented higher CD4 count of West Africans, it might be necessary to upwardly review the WHO recommended 350 cells/ $\mu$ l benchmark for instituting ART.

[Afr J Health Sci. 2007; 14:212-215]

\section{Introduction}

Using CD4 and CXCR4 cell surface molecules as receptor and co-receptor respectively; HIV infects Thelper lymphocytes, replicates within them and lyses the cells as the replicated virions are released extracellularly to infect yet other CD4 cells $[1,2]$. Consequently CD4+ T-helper lymphocytes are gradually depleted and the immune system crippled $[1,2]$. Since CD4 lymphocytes are the most crucial cells in adaptive immunity that direct and coordinate the functions of other adaptive immune cells (Blymphocytes, CD8 lymphocytes \& monocytes / macrophages), the devastating effect of HIV on the immune system is not surprising.

Given that HIV induced immunodeficiency is largely due to infection and gradual depletion of CD4+ T-helper cells, CD4 count has become a useful indicator of immune function in infected patients. Hence CD4 count along with viral load (HIV-RNA) is invaluable in management of HIV infection, particularly in monitoring response to anti-retroviral therapy (ART) $[3,4,5]$. CD4 count is said to be the most reliable prognostic indicator of immune response to therapy $[3,6,7]$, and is thus a major criterion in the $\mathrm{CDC} / \mathrm{WHO}$ classification of HIV infection, which is widely used to categorize patients for clinical management [8]. With the introduction of heavily subsidized ART by the Nigerian Federal government in several tertiary health institutions around the country - including Aminu Kano Teaching Hospital here in Kano - it became necessary to monitor the CD4 lymphocyte counts of HIV patients managed under the subsidized ART scheme. This study endeavours to appraise the baseline CD4 profile of HIV seropositive patients at the commencement of anti-retroviral treatment.

\section{Materials and Methods}

Six hundred adults were recruited for this study -100 healthy controls and 500 HIV seropositive patients. The HIV seropositives were recruited from patients attending the HIV/AIDS clinic at Aminu Kano Teaching hospital, Kano over a 15 month period from April 2002 to June 2003. Our healthy controls were randomly selected seronegative students of a local tertiary educational institution and seronegative pregnant women attending ante-natal clinc at the teaching hospital. 
Children were excluded from this study because initially the Federal Ministry of Health, subsidized ART scheme was only targeted at adults. Laboratory diagnosis of HIV infection was established by double ELISA technique (Capillus \& Immunocomb), and CD4 count was estimated manually by Dynal Enumeration Technique. The CD4 lymphocytes were counted prior to commencement of ART and at six month intervals thereafter. Only the baseline data at the beginning of therapy was used for this study.

\section{Results}

Of the 500HIV positive patients, 307 were males and 193 were females $(\mathrm{M}: \mathrm{F}=1.6: 1)$. Although the age range was quite wide (18-64 years), most patients (92\%) fell within the 3rd to 5th decades. About half of the patients (251cases) had AIDS as defined by CD4 count below 200 cells $/ \mu 1$ [8]. Seventy two percent of our study subjects (359 cases) had CD4 count $<350$ cells $/ \mu 1$ - the WHO laboratory criteria for instituting ART in a resource limited setting $[9,10]$ such as here in Northern Nigeria. Only 9.6\% (48 cases) had normal CD4 counts i.e. $>600$ cells $/ \mu$ l. The mean CD4 count of HIV seropsitive individuals in this study was 302 cells $/ \mu 1$. The healthy controls were aged between $18 \& 38$ years and had CD4 counts ranging from 697 to 1829 cells $/ \mu$ with a mean of $1295 \mathrm{cells} / \mu \mathrm{l}$.

Figure 1: age distribution of CD4 lymphocyte count among HIV patients in Kano

\begin{tabular}{llllllll}
\hline $\begin{array}{l}\text { CD4 count } \\
\text { Cells } / \mu \text { l }\end{array}$ & $<20$ years & $\begin{array}{l}20-29 \\
\text { years }\end{array}$ & $\begin{array}{l}30-39 \\
\text { years }\end{array}$ & $\begin{array}{l}40-49 \\
\text { years }\end{array}$ & $\begin{array}{l}50-59 \\
\text { years }\end{array}$ & $>60$ years & Total \\
\hline$<100$ & - & 17 & 47 & 30 & 3 & - & 97 \\
$100-199$ & 1 & 29 & 64 & 29 & 8 & 2 & 133 \\
$200-299$ & 1 & 27 & 42 & 25 & 3 & 1 & 99 \\
$300-399$ & 1 & 16 & 26 & 13 & 1 & - & 57 \\
$400-499$ & 2 & 11 & 12 & 9 & - & - & 34 \\
$500-599$ & 1 & 6 & 18 & 5 & 2 & - & 32 \\
$600-699$ & - & - & 8 & - & 1 & - & 9 \\
$700-799$ & 1 & 4 & 1 & - & 1 & - & 7 \\
$800-899$ & - & 1 & 4 & - & 2 & - & 7 \\
$900-999$ & - & 2 & 1 & 1 & - & - & 4 \\
$>1000$ & 1 & 4 & 9 & 5 & 1 & - & 20 \\
\hline Total & 8 & 117 & 232 & 118 & 22 & 3 & 500 \\
\hline
\end{tabular}

\section{Discussion}

Most (92\%) of the HIV positive patients in this study were within the 3rd to 5 th decades age bracket, which is not surprising in view of the fact that these are the most sexually active age group - heterosexual intercourse being the major mode of transmission in Africa [11]. However since children in the first two decades were largely excluded from this study, the age profile is obviously skewed in favour of adults, and accentuates the prominence of the sexually active age group. In Jos, a neighbouring northern Nigerian city, similar study reported this sexually active 3rd to 5 th decade age group comprised $46 \%$ (AIDS) and $59 \%$ (HIV positive) [12]. The lower proportion of the sexually active age group in their study could be partly explained by the inclusion of children. Males outnumbered females $(\mathrm{M}: \mathrm{F}=1.6: 1)$ in this series comprising $61.4 \%$ of our HIV seropositives. This is at variance with the well-documented fact that women are biologically and socially more vulnerable to HIV infection, particularly in the third world [11]. Socio-cultural restrictions on Muslim women here in Nigeria's Islamic north adversely affect hospital attendance and may explain the lower proportion of women in our study.

About half $(50 \%)$ of our HIV patients had AIDS as defined by CD 4 count $<200$ cells $/ \mu 1$ which is comparable to $54 \%$ in Jos, another northern Nigerian city [12]. Obviously the major reason for this high proportion of AIDS is because of late presentation, largely due to the fact that we are yet to imbibe the culture of voluntary screening for early detection and treatment. Fear of stigmatization, lack of awareness and inadequate trained counseling personnel are some of the factors militating against 
voluntary screening. Many patients only seek medical attention and are diagnosed when HIV infection becomes complicated by AIDS defining illnesses. Blacks in South Africa similarly presented late with advanced disease [13].

The mean CD4 count of our HIV patients was 302 cells/ $\mu 1$, which is higher than 270 cells $/ \mu 1$ in the UK [14] A comparative study between HIV patients in France and Francophone West Africa similarly documented higher CD4 counts in West Africans than in Europe [15]. The mean CD4 count for our healthy controls - 1295 cells/ $\mu 1$ - was also higher than the normal mean of 800 to 1050 cells $/ \mu 1$ in the Western world $[6,16]$. In Switzerland normal CD4 count was as low as 309 cells/ $\mu 1$ [17]. Njoku et al in Jos, also reported higher mean CD4 counts in healthy controls and HIV patients than in the Western world [12]. They attributed this "physiologic lymphocytosis" in Africans to common infections in our environment. This hypothesis is somewhat undermined by reports from East Africa which document lower CD4 count than in the Western world $[18,19]$. It thus appears that this "physiologic lymphocytosis" is peculiar to West Africans, which suggests that genetic factors might also be involved rather than just microbial infections from the environment.

The obvious implication of higher West African CD4 count in HIV management is that the widely adopted $\mathrm{WHO} / \mathrm{CDC}$ classification of HIV infection based on CD4 count may need to be modified for West Africans. Consequently Anglaret et a [15] propose threshold values of 250 and 700 cells/ $\mu$ l rather than the $\mathrm{CDC} / \mathrm{WHO}$ recommended 200 and 500 cells/ $\mu$ l for laboratory categorization of HIV infection. Thus it might be necessary to institute ART at higher CD4 counts of about $400-500$ cells $/ \mu 1$ in West Africa rather than the present 350 cells $/ \mu 1$. With the current benchmark of 350 cells/ $\mu 1$, over $70 \%$ of our patients already qualify for ART. An upward review of the benchmark translates to many more HIV seropositives requiring ART, which would strain the lean financial resources of the subsidized ART scheme.

\section{References}

1. Murray PR, Baron EJ, Jorgensen JH et al. HIV in: Manual of clinical microbiology. ASM press, Washington DC. 2000. p12531260.

2. Cotran RS, Kumar V, and Collins T. AIDS in: Robbins pathologic basis of disease. $W B$ Saunders Philadelphia. 1999. p236-242.

3. Mellors JW, Munoz A, Giorgi JV Margolick JB, Tassoni CJ, Gupta P, Kingsley LA,
Todd JA, Saah AJ, Detels R, Phair JP, Rinaldo CRJr. Plasma viral load \& CD4+ lymphocyte as prognostic markers of HIV-1 infection. Annals of Internal Medicine 1997; 126:946-954.

4. Lundgren JD, Mocroft A, Gatell JM, Ledergerber B, D'Arminio Monforte A, Hermans P, Goebel FD, Blaxhult A, Kirk O, Phillips AN, EUROSIDA Study Group. A clinically prognostic scoring system for patients receiving HAART: results from EUROSIDA study. Journal of Infectious Diseases. 2002; 185:178-187.

5. Ghani AC; de Wolf F; Ferguson NM; Donnelly CA; Coutinho R; Miedema F; Goudsmit J; Anderson RM. Surrogate markers for disease progression in treated HIV infection. Journal of Acquired Immune Deficiency Syndrome. 2001. 28:226-231.

6. Bartlett JG, Gallant JE. CD4 cell count in Medical management of HIV infection. John Hopkins Medicine, Baltimore. 2004. p18-20.

7. Chene G, Sterne JA, May M, Costagliola D, Lodergerber B, Phillips AN, Dabis F, Lundgren J, D'Arminio Monforte A, de Wolf F, Hogg R, Reiss P, Justice A, Lepon C, Staszowski S, Gill J, Fatkenheuer G, Egger ME, Antiretroviral Therapy Cohort Collaboration. Prognostic importance of initial response in HIV-1 infected patients starting potent anti-retroviral therapy: Analysis of prospective studies. Lancet 2003; 362:679-686.

8. Center for disease control \& prevention. 1993 Revised classification system and expanded surveillance definition for AIDS. MMWR. 1992; 41: 2-4

9. World Health Organization (WHO). Scaling up antiretroviral therapy in resource-limited settings: treatment guidelines for a public health approach. 2003 revision. Geneva: WHO; 2004. 68p

10. Federal Ministry of Health. Guidelines for the use of Anti-retroviral drugs in Nigeria. FMOH, Abuja. 2003. p35.

11. UNAIDS: HIV Epidemic - A global update. UNITED NATIONS World AIDS day report. Health Millions. 1998; 24: 3-5.

12. Njoku MO, Sirisena ND, Idoko JA, Jelpe D. CD4+ T-lymphocyte counts in patients with HIV-1 and healthy population in Jos, Nigeria. Nigerian Postgraduate Medical Journal. 2003; 10:135-139.

13. Burns F, Fakova A, Copas A. Africans with HIV present with advanced disease in the era of HAART. International Conference on 
AIDS. 2000; Jul 9-14; 13:68 (abstract no. LbPeE7131).

14. Saul J, Erwin J, Bruce JC, Peters B. Ethnic and demographic variations in HIV / AIDS presentation at two London referral centers 1995-9. Sexually Transmitted Infections. 2000; 76:215.

15. Anglaret X, Diagbouga S, Mortier E, Meda N, Verge-Valette V, Sylla-Koko F, Cousens S, Laruche G, Ledru E, Bonard D, Dabis F, Vande Perre P. CD4+ T-lymphocyte counts in HIV infections: Are European standards applicable to African patients? Journal of AIDS \& Human Retrovirology. 1997; 14:361-363.

16. Laurence J. T-cell subsets in health, infectious disease and idiopathic CD4+ Tlymphocytopenia. Annals of Internal Medicine. 1993; 119:55-62.

17. Bisset LR, Lung TL, Kaelin M, Ludwig E, Dubs RW. Reference values for peripheral blood lymphocytes phenotypes applicable to the healthy adult population in Switzerland. European Journal of Haematology. 2004; 72:203-212.

18. Urassa WK, Mbena EM, Swai AB, Gaines H, Mhalu FS, Biberfeld G. Lymphocyte subset enumeration in HIV seronegative and HIV-1 seropositive adults in Dar es Salaam Tanzania: determination of reference values in males and females and comparison of two flow cytometric methods. Journal of Immunological Methods. 2003; 277:65-74.

19. Wolday D, Tsegaye A, Messele T. Low absolute CD4 count in Ethiopians. Ethiopian Medical Journal. 2002; 40 suppl 1: 11-16. 